\title{
PRODUCTION PERFORMANCE AND BLOOD PROFILE OF CLIMBING PERCH Anabas testudineus Bloch CULTURED IN PEAT POND WITH DIFFERENT STOCKING DENSITIES
}

\author{
Ani Widiyati” , Adang Saputra, and Eri Setiadi \\ Research Institute for Freshwater Aquaculture and Fishery Extension \\ J. Sempur No. 1, Bogor 16129
}

(Received 6 March 2018; Final revised 10 January 2019; Accepted 10 January 2019)

\begin{abstract}
Climbing perch is one of economically-valued local fish in Indonesia, particularly in Borneo, Sumatra, and Java Islands. The fish has the potential to be developed as freshwater aquaculture species. The purpose of this experiment was to evaluate the production performance and blood profile of climbing perch cultured in peat pond with different stocking densities. The research was conducted in Kereng Bangkiray Village, Sebangau District, Palangkaraya City, Central of Borneo. Nine fish ponds sized $5.0 \mathrm{~m} \times 5.0 \mathrm{~m} \times 1.5 \mathrm{~m}$ were used. Nets with a mesh size of $1 \mathrm{~cm}$ measuring $2.0 \mathrm{~m} \times 1.5 \mathrm{~m} \times 1.0 \mathrm{~m}$ was installed in each fish pond for the experiment. The treatment consisted of different stocking densities, namely $15 \mathrm{fish} / \mathrm{m}^{2}, 30 \mathrm{fish} / \mathrm{m}^{2}$, and 45 $\mathrm{fish} / \mathrm{m}^{2}$. Fish with the body weight of $20 \pm 1.25 \mathrm{~g}$ were used. Fish were cultured for four months. An artificial diet containing 30\%protein was given with a feeding rate of $5 \%$ The experiment was designed in a complete randomized design. The result showed that the production performances (i.e. survival, specific growth rate, absolute weight, and biomass) were significantly higher at the densities of 15 and $30 \mathrm{fish} / \mathrm{m}^{2}$ than that of $45 \mathrm{fish} / \mathrm{m}^{2}(P<0.05)$. Blood profile such as glucose, erythrocyte, leucocyte, and hemoglobin were higher at the density of $45 \mathrm{fish} / \mathrm{m}^{2}$ except for hematocrit which was higher at the densities of 30 and $15 \mathrm{fish} / \mathrm{m}^{2}$. Water quality parameters such as dissolved oxygen, nitrite, nitrate, and ammonia at the densities of 15 and $30 \mathrm{fish} / \mathrm{m}^{2}$ showed better values than that of $45 \mathrm{fish} / \mathrm{m}^{2}$ stocking density. To optimize the productivity and maintain the optimum water quality condition, the optimal stocking density for climbing perch culture is suggested at $30 \mathrm{fish} / \mathrm{m}^{2}$.
\end{abstract}

\section{KEYWORDS: Anabas testudineus; production performance; blood profile; stocking density; peat pond}

\section{INTRODUCTION}

One of the fish species that have the potential to be cultured is climbing perch Anabas testudineus Bloch, locally called in Indonesia as "Papuyu". This fish is a very popular fish for consumption especially in Sumatra, Borneo, and Java Islands due to its delicious taste (Sukadi et al., 2009). Such popularity has caused a significant reduction in its wild stock. The culture effort of the fish species has been conducted by fish farmers using traditional techniques in peat ponds of Central and South of Borneo. However, the current production is relatively low due to low stocking density $\left(15 \mathrm{fish} / \mathrm{m}^{2}\right)$. The availability of peatland in Indonesia is ranging from 13.5-26.5 million ha distributed

\footnotetext{
\# Correspondence:Research Institute for Freshwater Aquaculture and Fishery Extension.

Jl. Sempur No. 1, Bogor 16129, Indonesia.

Tel. + 622518313200

E-mail: ani_widiyati@yahoo.co.id
}

mostly in Sumatra, Borneo, Celebes, and Papua Islands (Barchia, 2006). This offers an opportunity to develop climbing perch aquaculture which is known to have a high tolerance to such environment (Widiyati et al., 2016).

High stocking density in an intensive culture affects the growth and survival rate of cultured fish (Kusmini et al., 2017). Different stocking densities to culture climbing perch have been reported for example, $10 \mathrm{fish} / \mathrm{m}^{2}$ (Susila, 2016), $15 \mathrm{fish} / \mathrm{m}^{2}$ (Habib et al., 2015), and $14 \mathrm{fish} / \mathrm{m}^{2}$ (Khatune-Jannat et al., 2012). Khatune-Jannat et al. (2012) reported that the use of the high stocking density has resulted in low production performance compared to the lower stocking density. The effects caused by a high stocking density could be attributed to the increase of competition in term of space, locomotion, and food (Hermawan et al., 2012). 
In addition, stocking density can also affect the hematological parameters of fish (Salah \& Wael, 2011). For example, blood profile can be used as an indicator to determine fish stress condition (Moyle $\&$ Cech, 2004). Prihadi et al. (2017) reported that marble goby fingerling cultured at a density of $150 \mathrm{fish} / \mathrm{m}^{2}$ showed the highest glucose blood content than that of stocking densities of 100 dan $50 \mathrm{fish} / \mathrm{m}^{2}$. The authors also found that physiological responses of blood profile such as blood glucose, leucocyte, erythrocyte, hematocrit, and hemoglobin contents were better at the density of $50 \mathrm{fish} / \mathrm{m}^{2}$ than that of 100 and 150 $\mathrm{fish} / \mathrm{m}^{2}$.

Finding a balanced relationship between stocking density and fish blood profile constitute the importance of this in developing a better culture technique of climbing perch. Therefore, this experimental study was aimed at determining the production performance and blood profile of climbing perch cultured with different stocking densities in peat pond.

\section{MATERIALS AND METHODS}

The experiment was conducted in peat ponds owned by fish farmers in Kereng Bangkiray Village, Sebangau District, Palangkaraya City, Central Borneo Province from June to October 2016. Nine peat ponds sized $5.0 \mathrm{~m} \times 5.0 \mathrm{~m} \times 1.50 \mathrm{~m}$ were used. The pond surface was layered with plastic sheets. A rectangular net measuring of $2.0 \mathrm{~m}$ in length, $1.5 \mathrm{~m}$ in wide, and $1.5 \mathrm{~m}$ in depth $\mathrm{cm}$ with a mesh size of 1 inch was erected in the ponds to stock the fish. Water hyacinth, Eichhornia crassipes, was placed in each net to serve as a shelter covering $25 \%$ of the net area. A total of 300 ind. of climbing perch with an average weight of $20.0 \pm 1.25 \mathrm{~g}$ were used in this experiment and cultured for four months. A commercial diet containing $30 \%$ protein was fed to the stocked fish three times per day with a feeding rate of $5 \%$ body weight. The experimental design used a complete randomized design with three treatments and three replicates. Different stocking densities were as follows: A) $15 \mathrm{fish} / \mathrm{m}^{2}$; B) $30 \mathrm{fish} / \mathrm{m}^{2}$; and C) 45 $\mathrm{fish} / \mathrm{m}^{2}$.

Parameters of production performance consisting of survival rate, absolute body weight, specific growth rate (SGR), and biomass were observed. To obtain the absolute weight and specific growth rate, 20 fish were sampled every month (day 0, 30, 60, 90, and 120). For the survival rate, the number of fish were counted at the beginning and the end of the experiment. Fish body weight and biomass were measured using a digital weight scale (max. weight of $600 \mathrm{~g}$ ) with two decimal accuracy. Each parameter data was calculated according to the formula suggested by Effendie (2002). Two fish in each treatment were sampled before stocking into the net (day 0 ), at the middle (day 60), and the end of the experiment (day 120) for measurement of blood profile. Fish were anesthetized using Ocean Free Stabilizer ${ }^{\circledR} 10 \mathrm{mgL}^{-1}$ before its blood collected. Blood was collected from caudal vein using a syringe of 1.0 $\mathrm{mL}$, which was previously rinsed with anticoagulant, then transferred into a $0.5 \mathrm{~mL}$ tube. After that, 0.05 $\mathrm{mL}$ anticoagulant were added. The blood samples were analyzed in the laboratory. Hemoglobin, hematocrit, erythrocyte, and leucocyte were counted using Neubauer hemocytometer following Maheswaran (2008) method. Blood glucose was measured using tool kit blood glucose test meter (Gluco Dr. Auto AGM 2100). After blood collection, the fish were placed back into their initial ponds.

Water quality parameters such as temperature, $\mathrm{pH}$, and dissolved oxygen (DO) were measured using a Hanna water quality instrument (HI9829). Water samples were collected from each pond at the beginning (day 0), middle (day 60), and end (day 120) of the experiment and analyzed in the laboratory to determine nitrite, nitrate, and ammonia concentrations. Concentrations of nitrite, nitrate, and ammonia were determined following the standard procedures provided in SNI (Indonesian National Standar) 06-6989.92005,6989.79-2011, and 06-6989.30-2005, respectively. All data on production performance (survival, SGR, absolute weight, biomass) were statistically analyzed using ANOVA and followed by the Duncan test as a post hoc analysis if any significant difference was found between the treatments. Hemoglobin, hematocrit, erythrocyte, and leukocyte counts were descriptively analyzed. Water quality parameters such as $\mathrm{pH}$, temperature, DO, ammonia, nitrite, and nitrate were also descriptively analyzed.

\section{RESULTS AND DISCUSSION}

\section{Production Performance}

The results of the survival rate, absolute weight, specific growth rate (SGR), and biomass of climbing perch are shown in Figure 1.

The survival rate of climbing perch cultured at the stocking density of $15 \mathrm{fish} / \mathrm{m}^{2}(77.33 \pm 5.51 \%$ was the highest, followed by $30 \mathrm{fish} / \mathrm{m}^{2}(75.00 \pm 2.00 \%)$ and $45 \mathrm{fish} / \mathrm{m}^{2}(55.00 \pm 1.00 \%$ (Figure 1a). The survival rates between fish stocked at 15 and $30 \mathrm{fish} / \mathrm{m}^{2}$ were not significantly different $(P>0.05)$, but they were significantly different from that of fish stocked at the density of $45 \mathrm{fish} / \mathrm{m}^{2}(\mathrm{P}<0.05)$. The low survival rate in the latter means that the stocking density has reached a point where fish are easier to get 

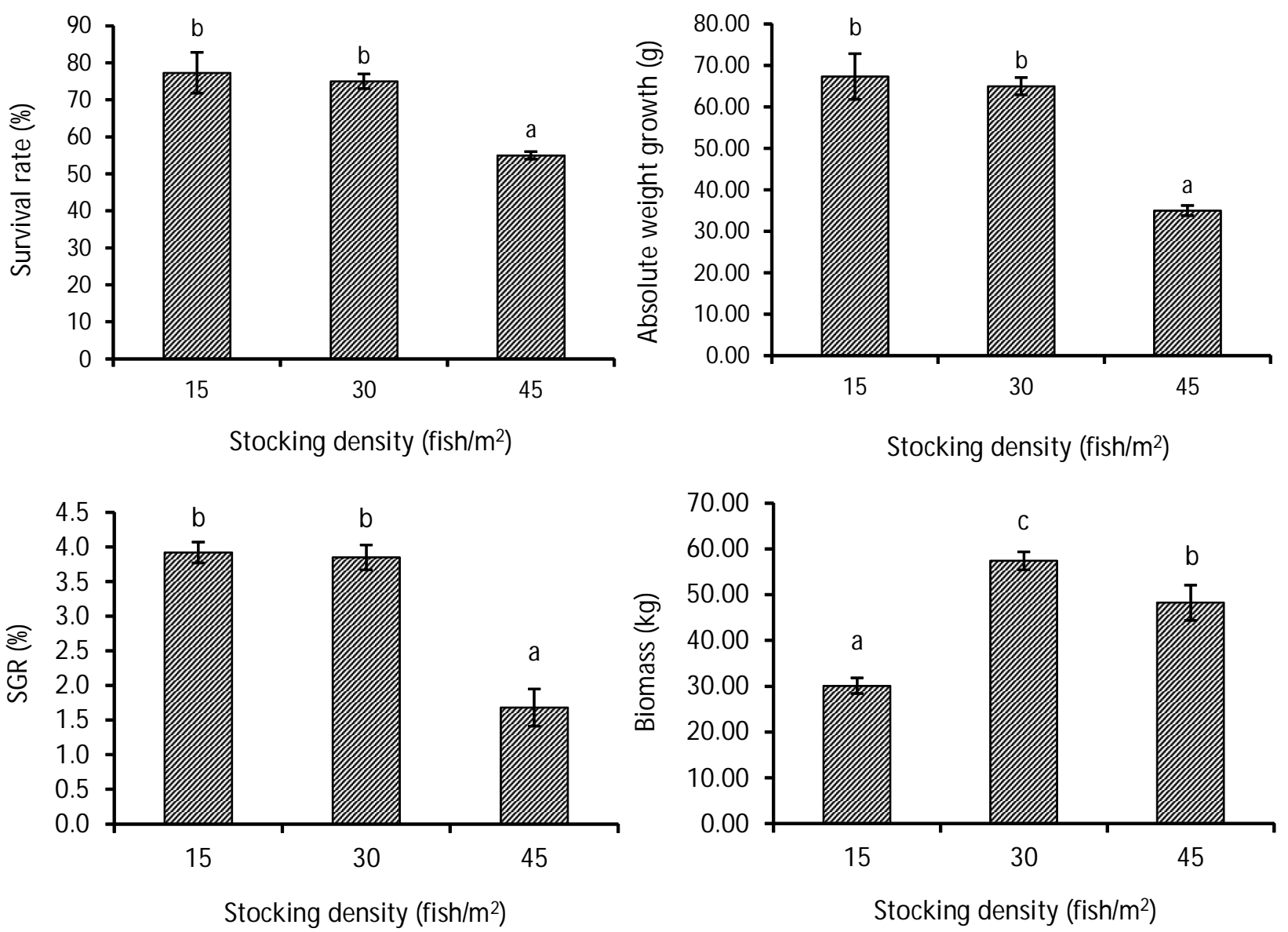

Remarks: Bars having the same letter are not significantly different $(P>0.05)$

Figure 1. Production performance of climbing perch cultured at different stocking densities; a) survival rate; b) absolute weight); c) SGR; and d) biomass.

stressed due to competition of space, locomotion, and food (Prihadi et al., 2017). Fish also become weaker and easily infected by diseases, more sensitive to water quality change, and prone to mortality. Khatune-Jannat et al. (2012) stated that climbing perch cultured at higher stocking density had a low survival rate compared to low stocking density.

The absolute weight growth at the stocking density of $15 \mathrm{fish} / \mathrm{m}^{2}(67.33 \pm 5.51 \mathrm{~g})$ was the highest, followed by $30 \mathrm{fish} / \mathrm{m}^{2}(65.00 \pm 2.00 \mathrm{~g})$, and $45 \mathrm{fish} /$ $\mathrm{m}^{2}(35 \pm 2.00 \mathrm{~g})$ (Figure $1 \mathrm{~b}$ ). The absolute weights gained by fish at the stocking densities of 15 and 30 $\mathrm{fish} / \mathrm{m}^{2}$ were found significantly different compared to $45 \mathrm{fish} / \mathrm{m}^{2}(\mathrm{P}<0.05)$. This confirms that climbing perch cultured at high density would suffer from high competition in terms of space, food, and locomotion than that of low density leading to decreased growth. Rahman et al. (2016); Rahman \& Verdegem (2010) reported that fish cultured at low density had less competition on space, food, and locomotion, resulting in maximum growth and weight gain.
Specific growth rate (SGR) decreased following the increase in stocking density. The highest of SGR (3.92 $\pm 0.15 \%$ was achieved by fish stocked at 15 $\mathrm{fish} / \mathrm{m}^{2}$, followed by $30 \mathrm{fish} / \mathrm{m}^{2}(3.85 \pm 0.18 \%$, and the lowest was $45 \mathrm{fish} / \mathrm{m}^{2}$ (1.68 $\pm 0.77 \%$ (Figure $1 \mathrm{c}$ ). This indicates that stocking density strongly influences fish growth concerning energy use and food competition. Similar results were reported by Rahman et al. (2010) and Prakoso et al. (2016) that high stocking density has resulted in low SGR and production of cultured fish such as Labeo calbasu, Cirrhinus cirrhosus, and Nemacheilus fasciatus.

The biomass gain of climbing perch cultured at the density of $30 \mathrm{fish} / \mathrm{m}^{2}(57.38 \pm 1.96 \mathrm{~kg})$ was the highest, followed by $45 \mathrm{fish} / \mathrm{m}^{2}(48.23 \pm 3.85 \mathrm{~kg})$, and the lowest was $15 \mathrm{fish} / \mathrm{m}^{2}(30.10 \pm 1.70 \mathrm{~kg})$ (Figure 1d). All treatments showed significant differences in terms of biomass gain $(P<0.05)$. The biomass gain is affected by fish growth and survival rate. In the present experiment, the stocking density of $30 \mathrm{fish} /$ $\mathrm{m}^{2}$ showed higher values of absolute weight, SGR, 
and survival than that of 15 and $45 \mathrm{fish} / \mathrm{m}^{2}$ (Figure 1ac). A similar result was reported by Prihadi et al. (2017) who found that high stocking density of marble goby with a weight range of 4-5 g produced high biomass value due to high survival rate.

\section{Blood Profile}

The results of blood profile (blood glucose, hemoglobin, hematocrit, erythrocyte, and leucocyte) are shown in Figure 2. The patterns of blood glucose and leucocyte increased with the increase of stocking density while hemoglobin decreased. Hematocrit recorded showed increase values, from $20.70 \%$ to $24.70 \%$ and from $20.70 \%$ to $22.20 \%$ with the increase of stocking densities, 15 and $30 \mathrm{fish} / \mathrm{m}^{2}$, respectively, with the exception for $45 \mathrm{fish} / \mathrm{m}^{2}$ (from $20.70 \%$ to
$17.70 \%$. Erythrocyte content showed the same patterns in all treatments (Figure 2). The present experiment revealed that stocking density affects blood glucose and leucocyte due to increased fish stress. The highest blood glucose level at a density of 45 $\mathrm{fish} / \mathrm{m}^{2}$ indicated that the fish stress condition was predominantly caused by the high stocking density. In stress condition, fish responded by increasing its blood glucose is naturally increased to keep a steady homeostatic condition, which have resulted in the decline of insulin (Royan et al., 2014). If the environmental condition is not suitable for fish (increased stress), chromaffin cell will release catecholamine, adrenaline, noradrenaline hormones into the blood (Reid et al., 1998). These stress hormones will join with cortisol hormone leading to the increase of blood

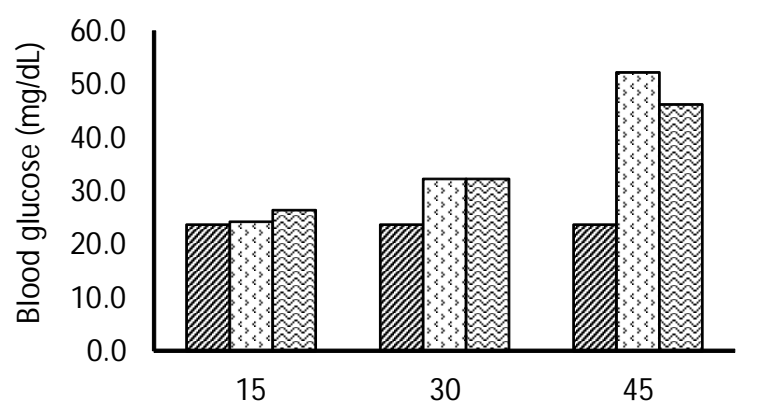

At the beginning $⿴$ In the midle $\otimes$ At the end Stocking denisty (fish/m²)

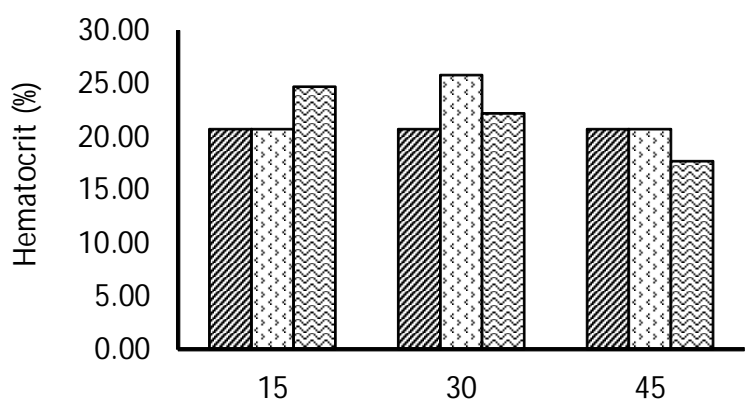

At the beginning 0 In the middle At the end Stocking density $\left(\mathrm{fish} / \mathrm{m}^{2}\right)$

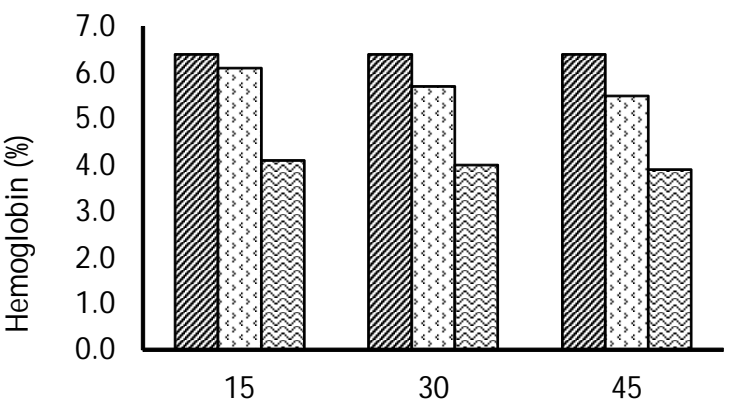

At the beginning $⿴$ In the midle $\otimes$ At the end Stocking density (fish/m²)

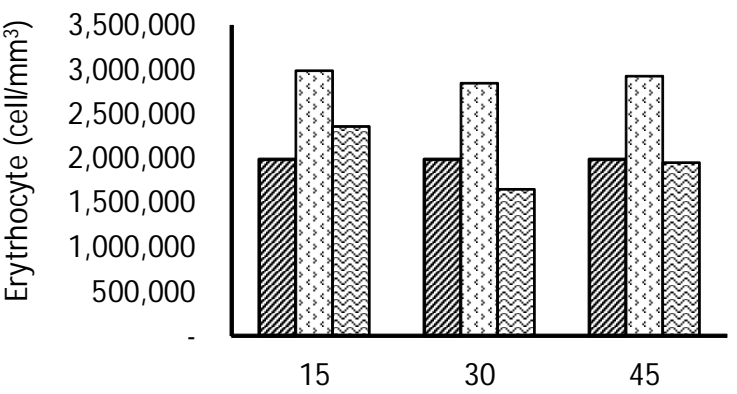

\# At the beginning $\square$ In the midle $\square$ At the end Stocking density $\left(\right.$ fish $\left./ \mathrm{m}^{2}\right)$

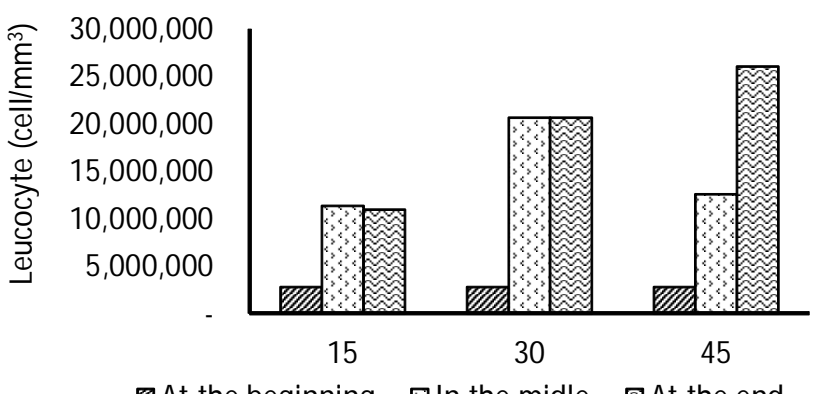

At the beginning $⿴ 囗 十$ In the midle $⿴$ At the end

Stocking density (fish/m²)

Figure 2. Blood profile of climbing perch at the beginning, middle, and end of culture period with different stocking densities: a) blood glucose; b) hemoglobin; c) hematocrit; d) erythrocyte; and e) leucocyte. 
glucose in the blood via glucogenesis and glycogenoIysis (Iwama et al., 1999). Fish blood glucose levels were $6.5 \mathrm{mg} / \mathrm{dL}$ and $32.3 \mathrm{mg} / \mathrm{dL}$ at stocking densities of 15 and $30 \mathrm{fish} / \mathrm{m}^{2}$, respectively, which were lower than that of $45 \mathrm{fish} / \mathrm{m}^{2}(46.3 \mathrm{mg} / \mathrm{dL})$. This condition indicated that the fish cultured with the stocking densities were in a comfortable condition; thus, stress did not occur due to low competition on space, locomotion, and food. Increasing blood glucose and leucocyte at the end of the experiment at the density of $45 \mathrm{fish} / \mathrm{m}^{2}$ clearly indicated fish were suffering from stress and unhealthy condition. Eventually, the number of fish was decreasing due to mortality during the culture period resulting in low survival (Figure 1a-d). Hemoglobin concentration had been used to distinguish the effect of stocking density on fish health and stress (Salah \& Wael, 2011). Increase of leucocyte is closely related to high stocking density due to stress of fish and to protect against themselves in unfavored environmental condition. Leucocyte as a part of the immune response of fish had been reported by Motlagh et al. (2010). It is produced by thymus and kidney and distributed in the fish body (Irianto, 2005). A similar result from Naderi et al. (2017) revealed that high stocking density can lead to an increase of leucocyte content and affect the overall fish's immune level. Ellis et al. (2002) argued that fish living in inappropriate stocking density could have growth impairment and reduced immune capability.

\section{Water Quality}

Temperature, pH, DO, ammonia, nitrite, and nitrate can affect fish growth and survival (Oliveira et al., 2012). Water quality parameters i.e. ammonia, nitrite, and nitrate values had increased with the increase of stocking density while temperature and $\mathrm{pH}$ were the relatively constant in all treatments, except for dissolved oxygen (DO) showing a decrease with the increase of stocking density (Table 1). Ammonia, nitrite, nitrate, and DO concentrations at a density of $45 \mathrm{fish} / \mathrm{m}^{2}$ (Table 1) were outside the ranges of recommended values for fish culture suggested by
Boyd (1990). This result validates that stocking density indirectly influences water quality in fish culture environment where poor water quality (higher contents of ammonia, nitrite, and nitrate) usually corresponds to higher stocking density. The degradation of water quality is caused by higher release rate and accumulation of waste products (i.e., fesses, urine, and uneaten food). Setiadi \& Setidjaningsih, (2011) reported that the increased of ammonia, nitrite, and nitrate concentrations corresponded with length of culture period due to accumulation of fish faecal and feed wastes.

The $\mathrm{pH}$ values in all treatments were below the recommended value for fish culture (Table 1 ). Sembiring et al. (2011) reported that low pH value (down to $\mathrm{pH}$ 4) did not affect climbing perch growth and survival. Similarly, it is argued here that the effect of low pH values on climbing perch in this study was minimal on the fish health and growth. Climbing perch has adapted to the low $\mathrm{pH}$ of peat environment where Rosli et al. (2010) stated that the pH values usually range between 3 and 5.5 due to high rate decomposition of organic matter.

\section{CONCLUSION}

The present experiment is to definite the optimal stocking density. Based the result could be concluded that to maximize production of the climbing perch culture, the optimal stocking density should have $30 \mathrm{fish} / \mathrm{m}^{2}$ in order to reach the optimal in term of survival, growth, and biomass. The present experiment revealed that blood glucose and hematocrit only were affected by stocing density. In the future research should have focused on duration of the culture which reach to consumption size.

\section{REFERENCES}

Barchia, M.F. (2006). Agroekosystem peat dan transformation charbon. Yogyakarta: Gadjah Mada University Press.

Table1. The range of water quality parameters $(\mathrm{pH}$, temperature, $\mathrm{DO}$, ammonia, nitrite, and nitrate) observed during the experiment

\begin{tabular}{lcccc}
\hline \multirow{2}{*}{ Parameters } & \multicolumn{3}{c}{ Treatments $\left(\mathbf{f i s h} / \mathbf{m}^{\mathbf{2}}\right)$} & Optimum \\
\cline { 2 - 4 } & $\mathbf{1 5}$ & $\mathbf{3 0}$ & $\mathbf{4 5}$ & range \\
\hline pH & $5.00-5.50$ & $5.00-5.50$ & $5.00-5.50$ & $6-9^{1)}$ \\
Temperature $\left({ }^{\circ} \mathrm{C}\right)$ & $29.00-31.00$ & $29.00-31.00$ & $29.00-31.00$ & $26-30^{1,2)}$ \\
Dissolved oxygen $(\mathrm{mg} / \mathrm{L})$ & $3.20-5.56$ & $3.00-4.50$ & $2.80-3.00$ & $? 3^{1,2)}$ \\
Ammonia $(\mathrm{mg} / \mathrm{L})$ & $0.05-0.18$ & $0.05-0.70$ & $0.19-1.11$ & $0.05-0.92^{3)}$ \\
Nitrite $(\mathrm{mg} / \mathrm{L})$ & $0.11-0.2$ & $0.21-0,80$ & $0.51-1.08$ & $0.02^{1,2)}$ \\
Nitrate $(\mathrm{mg} / \mathrm{L})$ & $0.21-0.38$ & $0.20-0.47$ & $0.21-0.75$ & $0.2^{1,2)}$ \\
\hline
\end{tabular}

Remarks: 1) Government regulation No. 82 (2001); 2) Boyd (1990); 3) Kohinoor et al . (2016) 
Boyd, C.E. (1990). Water quality in pond aquaculture. Alabama (US): Birmingham Publishing Co.

Effendie, M.I. (2002). Fishery biology. Yogyakarta: Yayasan Pustaka Nusatama, 163 pp.

Ellis, T., North, B., Scott, A.P., Bromage, N.R., Porter, M., \& Gadd, D. (2002). The relationship between stocking density and welfare in farmed rainbow trout. J. Fish Biol., 61, 493-531.

Government Regulation. (2001). Government Regulation of Republic of Indonesia Number 82. Water quality management and water pollution protection. Jakarta (ID): Sekretariat Negara, 46 pp.

Habib, K.A., Newaz, A.W., Badhon, M.K., Naser, M.N., $\&$ Shahabuddin, A.M. (2015). Effects of stocking density on growth and production performance of cage reared climbing perch Anabas testudineus of high yielding Vietnamese stock. World Journal of Agricultural Sciences, 11, 19-28.

Hermawan, A.T., Iskandar, \& Subhan, U. (2012). Effect of stocking density on survival and growth of catfish Clarias gariepinus Burch. in pond, Kalimenir Indramayu. Jurnal Perikanan dan Kelautan, 3, 8593.

Irianto, A. (2005). Patologi ikan teleostei. Yogyakarta (ID): Gadjah Mada University Press.

Iwama, G.K., Vijayan, M.M., Forsyth, R.B., \& Ackerman, P.A. (1999). Heat shock proteins and physiological stress in fish. Am. Zool., 39, 901-909.

Khatune-Jannat, M., Rahman, M.M., Bashar, M.M., Ahamed, M.F., \& Hossain, M.Y. (2012). Effects of stocking density on survival, growth, and production of Thai climbing perch Anabas testudineus under fed ponds. Sains M alaysiana, 41, 1205-1210.

Kohinoor, A.H.M., Rahman, Md.M., Islam, S., \& Yohirmahmud. (2016). Growth and production performance of climbing perch Thai Koi and Vietnamese Koi Stain Anabas testudineus in Bangladesh. International Journal of Fisheries an Aquatic studie, 4(1), 354-357.

Kusmini, I.I., Putri, F.P., \& Radona, D. (2017). Growth and survival of post larvae on "lalawak" Barbonymus balleroides Valenciennes, 1842 fish in aquarium with different stocking density. Jurnal Iktiologi Indonesia, 17, 21-27.

Maheswaran, A.R., Devapaul, S.M., Velmurugan, B., \& Ignacimuthu, S. (2008). Hematological studies of freshwater fish, Clarias batrachus L. exposed to mercuric chloride. IJIB, 2, 49-54.

Motlagh, S.P., Zarejabad, A.M., Nasrabadi, R.G., Ahmadifar, E., \& Molaee, M. (2010). Haematology, morphology and blood cells characteristics of male and female Siamese fighting fish Betta splendens. Comp. Clin. Pathol., p. 15-21.
Moyle, P.B. \& Cech, Jr.J.J. (2004). Fishes. An Introduction to Ichthyology. 5th ed. USA: Prentice Hall Inc.

Naderi, M., Jafaryan, H., \& Jafaryan, S. (2017). Effect of different stocking densities on hematological parameters and growth performance of great sturgeon Huso huso Linnaeus, 1758 juveniles. Iranian Journal of Aquatic Animal Health, 3, 1-10.

Oliveira, E.G., Pinheiro, A.B., Oliveira, V.Q., Junior, A.R., Moraes, M.G., Rocha I.R., Sousa, R.R., \& Costa, F.H. (2012). Effect of stocking density on the performance of juvenile pirarucu Arapaima gigas in cages. Aquaculture, 3, 96-101.

Prakoso, V.A., Ath-thar, M.H.F., Subagja, J., \& Kristanto, A.H. (2016). Growth performance of barred loach Nemacheilus fasciatus at different stocking density on exsitu environment. Jurnal Riset Akuakultur, 11(4), 355-362.

Prihadi, T.H., Saputra, A., Huwoyon, G.H., \& Pantjara, B. (2017). The effect of stocking density on survival rate, growth, and hematological parameters of sand goby Oxyeleotris marmorata juvenile. Jurnal Riset Akuakultur, 12, 341-350.

Rahman, Md.M., Mondal, D.K., Amin, Md.R., \& Muktadir, M.G. (2016). Impact of stocking density and growth and production performance of monosex tilapia Orechromis niloticus in ponds. Asian J. Med. Biol. Res., 2(3), 471-476.

Rahman, M.M. \& Verdegem, M.C.J. (2010). Effects of intra and interspecific competition on diet, growth and behaviour of Labeocal basu Hamilton and Cirrhinus cirrhosus Bloch. Applied Animal Behavioural Science, 128, 103-108.

Reid, S.G., Bernier, N.J., \& Perry, S.F. (1998). The adrenergic stress response in fish: Control of catecholamine storage and release. Comp. Biochem. and Physiol. Part C, 120, 1-27.

Rosli, N., Gandaseca, S., Ismail, J., \& Jailan, M.I. (2010). Comparative study of water quality at different peat swamp forest of Batang Igan, Sibuk Sarawak. American Journal of Environmental Science, 6, 416421.

Royan, F., Rejeki, S., \& Haditomo, A.H.C. (2014). Effect of salinity level on blood profile in nile tilapia Oreochromis niloticus. Journal of Aquaculture Management and Technology, 3, 109-117.

Salah, M.K. \& Wael, A.O. (2011). Effect of different stocking densities on hematological and biochemical parameters of silver carp, Hypophthalmichthys molitrix fingerlings. Life Science Journal, 8, 580- 586.

Sembiring, A.P.V., Shafrudin, Budiardi, D., \& Tatag, B. (2011). Growth and survival of climbing perch Anabas testudineus larvae at pH 4, 5, 6, 7. Thesis, Bogor Agricultural University, Indonesia. 
Setiadi, E. \& Setidjaningsih, L. (2011). Improving water quality and productivity of tilapia Oreochromis niloticus using constructed wetland. Indonesian Aquaculture Journal, 6(1), 107-122.

Standar Nasional Indonesia (SNI) 06-6989.30-2005. Water and waste water-Part 30: Test procedure of ammonia concentration using spectrophotometer. ICS 13.060.01.

Standar Nasional Indonesia (SNI) 06-6989.9-2005. Water and waste water-Part 9: Test procedure of nitrite $\left(\mathrm{NO}_{2}-\mathrm{N}\right)$ by spectrophotometer. ICS 13.060.50.

Standar Nasional Indonesia (SNI) 6989.79-2011. Water and waste water-Part 79: Test procedure of nitrate $\left(\mathrm{NO}_{3}-\mathrm{N}\right)$ with cadmium reduction using UVvisible spectrophotometer. ICS 13.060.050.
Sukadi, F., Kristanto, A.H., Nugroho, E., Komarudin, O., Widiyati, A., Gustiano, R., Djajasewaka, H., \& Kusmini, I.I. (2009). Local commodity candidate of freshwater potential for fish culture in Shout Borneo. Proceading Forum Inovasi Teknologi Akuakultur. Research Center for Aquaculture, Marine and Fisheries Agency, 11 pp.

Susila, N. (2016). Effect of stocking density on survival and growth on betok Anabas testudineus in the basin culture. Jurnal IImu Hewani Tropika, 5, 72-75.

Widiyati, A., Saputra, A., \& Ardi, I. (2016). Climbing perch Anabas testudineus culture with optimal stocking density in peat pond. Proceeding of Aquaculture Technology Innovation Forum. 2016, Research and Development Center for Aquaculture, Jakarta, p. 155-161. 